\title{
Levels of mortality, education, and social conditions in the 107 local education authority areas of England
}

\author{
J N Morris, D B Blane, I R White
}

\begin{abstract}
Study objective - To investigate the relationships between education, social conditions, and mortality.

Design - An ecological study relating several measures of mortality to local rates of educational attainment at age 15/16 years and scores on the Department of the Environment's index of local conditions.

Setting - England and its 107 local education authority areas in 1991 .

Main results - Educational attainment was closely associated with all cause, coronary, and infant mortality and strongly associated with the index of local conditions. This social index was also closely associated with all the measures of mortality. In multiple regression, the social index was the stronger correlate of all cause mortality but for coronary and infant mortality, educational attainment remained highly statistically significant.

Conclusions - Area levels of both educational attainment and deprivationaffluence are strong correlates of local mortality rates in England. In these analyses educational attainment may be indexing the general cultural level of a community. Preliminary investigation with these ecological data suggests that deprivation-affluence has the stronger association but a surer assessment of their relative importance will require individual level information.
\end{abstract}

( $\mathcal{F}$ Epidemiol Community Health 1996;50:15-17)

Health Promotion

Sciences Unit,

London School of

Hygiene and Tropical

Medicine,

Keppel Street,

London WC1E 7HT.

$\mathrm{J} N$ Morris

Academic Department of Psychiatry,

Charing Cross and

Westminster Medical

School

D B Blane

Medical Statistics

Unit,

London School of

Hygiene and Tropical

Medicine,

London

I R White

Correspondence to:

Dr J N Morris.

Accepted for publication October 1995 rivation-affluence, measured in a variety of ways, and educational attainment are independently related to many aspects of health during early adulthood. The OPCS longitudinal study has shown that male adult mortality varies with both educational attainment and occupational social class. ${ }^{10}$

The presently reported study adds to these results because, unlike the birth cohorts, its outcome measure of health is mortality, and its measure of deprivation-affluence is more precisely targeted than the occupational social classes which were used in the longitudinal study analyses. It is an ecological study, which has the disadvantage of being hard to interpret but the advantage that it may identify factors that genuinely work at the ecological level.

\section{Methods}

All our data are recent government statistics, summarised for the 107 local education authority (LEA) areas of England. Those concerning education and social conditions refer to 1991, while the mortality data are for the period 1990-92. Our measure of educational attainment is the proportion of boys and girls in each LEA area who obtained grades A, B, or $\mathrm{C}$, in at least five subjects in the General Certificate of Secondary Education (GCSE) examination at age $15 / 16$ years.

For our measure of deprivation-affluence in each LEA area, we have used the Department of the Environment's summary index of local conditions. ${ }^{11}$ This is a composite of the social conditions of local populations, constructed from seven items from the 1991 census and a further six items from various other sources. We have omitted the two items in the index which refer to adult mortality and educational attainment at age 16 years, because we wish to treat these as separate variables in our analysis. The index of local conditions, thus amended, consists of two measures of unemployment (total and long term), two household measures (crowding, basic amenities), car ownership, two measures of childhood conditions (low earning households and unsuitable accommodation), two neighbourhood characteristics (house contents insurance premiums and derelict land) and the proportions of adults receiving Income Support and of 17 year olds no longer in fulltime education. An index was constructed by summing these 11 measures, after first standardising each measure to a mean of zero and a standard deviation of one. 
Table 1 Mean deprivation and mortality rates for local educational authorities of England ranked by GCSE pass rate

\begin{tabular}{|c|c|c|c|c|c|c|}
\hline \multirow{3}{*}{$\begin{array}{l}\text { GCSE pass rate } \\
\text { sextile (1991-92) }\end{array}$} & \multirow{3}{*}{$\begin{array}{l}\text { Mean social } \\
\text { deprivation } \\
\text { index (1991)* }\end{array}$} & \multicolumn{5}{|c|}{ Mean mortality (1990-92) per 1000} \\
\hline & & \multicolumn{2}{|c|}{$\begin{array}{l}\text { All causes, all } \\
\text { ages }\end{array}$} & \multicolumn{2}{|c|}{$\begin{array}{l}\text { Comnary heart disease, } \\
\text { ages } 15-64 y\end{array}$} & \multirow[t]{2}{*}{ Infant } \\
\hline & & Male & Female & Male & Female & \\
\hline $\begin{array}{l}\text { Least successful } \\
\text { 2nd } \\
\text { 3rd } \\
\text { 4th } \\
\text { 5th } \\
\text { Most successful }\end{array}$ & $\begin{array}{r}12 \cdot 59 \\
5 \cdot 26 \\
-0.94 \\
-2 \cdot 67 \\
-5 \cdot 35 \\
-7 \cdot 84\end{array}$ & $\begin{array}{r}11 \cdot 5 \\
11 \cdot 2 \\
10 \cdot 7 \\
10 \cdot 2 \\
9 \cdot 8 \\
9 \cdot 1\end{array}$ & $\begin{array}{l}6 \cdot 8 \\
6 \cdot 8 \\
6 \cdot 6 \\
6 \cdot 4 \\
6 \cdot 2 \\
5 \cdot 7\end{array}$ & $\begin{array}{l}1 \cdot 42 \\
1.40 \\
1 \cdot 32 \\
1 \cdot 19 \\
1 \cdot 10 \\
0.94\end{array}$ & $\begin{array}{l}0 \cdot 43 \\
0 \cdot 42 \\
0 \cdot 38 \\
0 \cdot 31 \\
0 \cdot 27 \\
0 \cdot 22\end{array}$ & $\begin{array}{l}8 \cdot 3 \\
8 \cdot 1 \\
7 \cdot 7 \\
7 \cdot 2 \\
6 \cdot 9 \\
5 \cdot 9\end{array}$ \\
\hline $\begin{array}{l}\text { Correlation with } \\
\text { GCSE pass rate }\end{array}$ & $-0 \cdot 89$ & -0.77 & -0.64 & -0.68 & -0.69 & $-0 \cdot 60$ \\
\hline
\end{tabular}

* Mean for England $=0$; positive value $=$ deprived, negative value $=$ affluent.

$\mathrm{GCSE}=$ General Certificate of Secondary Education.

Contemporary mortality data for each LEA area have kindly been provided by the OPCS: specifically, (i) age standardised all cause mortality per 1000 at all ages, for males and females separately; (ii) age standardised coronary heart disease mortality per 1000 at ages 15-64, males and females separately; and (iii) infant mortality per 1000 live births, males and females combined. (i) and (ii) may be regarded as "adult" mortality.

Several methods have been used to examine these data. The 107 LEAs of England have been ranked according to their pass rates in the GCSE examination and divided into sextiles; lowest sextile to $25 \cdot 1 \%, 29 \cdot 7 \%, 35 \cdot 1 \%, 37 \cdot 6 \%$, $41 \cdot 4 \%$, highest sextile to $47 \%$. The mean rate of social deprivation-affluence for each sextile group of LEAs has been calculated, as have the mean rates for the various measures of mortality. The strength of the relationship between the examination pass rate and (a) the index of social conditions and (b) each measure of mortality was measured by rank correlation of the 107 LEA areas.

The sextile analysis and the rank correlations have been repeated using the social index scores instead of the GCSE pass rates as the independent variable. The mean for the social index score for England equals zero, positive values indicate deprivation, negative values affluence. The highest social index scores in the sextiles were $-7 \cdot 5$ (most affluent), $-5 \cdot 5$, $-2 \cdot 2,1 \cdot 9,7 \cdot 7,23 \cdot 1$ (most deprived).

Finally, to investigate the hypothesis that local mortality is related to deprivation-affluence mainly through local standards of education, a multiple regression ${ }^{12}$ of each mortality

Table 2 Mean GCSE pass rate and mortality rates of local educational authorities of England ranked by social deprivation index

\begin{tabular}{|c|c|c|c|c|c|c|}
\hline \multirow{3}{*}{$\begin{array}{l}\text { Social deprivation } \\
\text { sextile (1991) }\end{array}$} & \multirow{3}{*}{$\begin{array}{l}\text { Mean GCSE } \\
\text { pass rate } \\
(1991-92)\end{array}$} & \multicolumn{5}{|c|}{ Mean mortality (1990-92) per 1000} \\
\hline & & \multicolumn{2}{|c|}{$\begin{array}{l}\text { All causes, all } \\
\text { ages }\end{array}$} & \multicolumn{2}{|c|}{$\begin{array}{l}\text { Coronary heart disease, } \\
\text { ages } 15-64 y\end{array}$} & \multirow[t]{2}{*}{ Infant } \\
\hline & & Male & Female & Male & Female & \\
\hline $\begin{array}{l}\text { Most deprived } \\
\text { 2nd } \\
\text { 3rd } \\
\text { 4th } \\
\text { 5th } \\
\text { Most affluent }\end{array}$ & $\begin{array}{l}22 \cdot 3 \% \\
28 \cdot 4 \% \\
32 \cdot 5 \% \\
37 \cdot 8 \% \\
38 \cdot 6 \% \\
42 \cdot 3 \%\end{array}$ & $\begin{array}{r}11 \cdot 4 \\
11.3 \\
10.9 \\
10 \cdot 0 \\
9.5 \\
9 \cdot 1\end{array}$ & $\begin{array}{l}6 \cdot 7 \\
7 \cdot 0 \\
6 \cdot 8 \\
6 \cdot 3 \\
6 \cdot 0 \\
5 \cdot 8\end{array}$ & $\begin{array}{l}1.33 \\
1.47 \\
1.37 \\
1.19 \\
1.05 \\
0.92\end{array}$ & $\begin{array}{l}0 \cdot 38 \\
0 \cdot 44 \\
0 \cdot 42 \\
0 \cdot 30 \\
0 \cdot 25 \\
0 \cdot 22\end{array}$ & $\begin{array}{l}8 \cdot 1 \\
8 \cdot 4 \\
7 \cdot 5 \\
7 \cdot 1 \\
6 \cdot 8 \\
6 \cdot 1\end{array}$ \\
\hline $\begin{array}{l}\text { Correlation with } \\
\text { social deprivation } \\
\text { index }\end{array}$ & -0.89 & $0 \cdot 81$ & 0.65 & $0 \cdot 71$ & 0.67 & 0.55 \\
\hline
\end{tabular}

index on the sextile of deprivation score (entered as a continuous variable in order to assess the trend) was performed, adjusted for sextile of GCSE pass rate (entered as a categorical variable to give the fullest possible adjustment). These results are presented as the fitted mortality values at the lowest and highest sextiles of deprivation. The corresponding analysis was performed on GCSE pass rate, adjusted for sextile of social deprivation.

\section{Results}

Table 1 displays characteristics of the LEA areas grouped into sextiles by their GCSE pass rates. The second column shows the average rate of social deprivation; positive figures indicate relative deprivation, negative figures relative affluence. The succeeding columns record the corresponding mean mortality rates. The bottom row presents the correlations between examination pass rate and each of the other variables in the 107 individual LEA areas. The sextile group of LEAs with the most successful examination pass rate has the most affluent social index score and the lowest rates on all five measures of mortality. Mean deprivationaffluence scores and mortality rates increase in a stepwise manner from the highest to the lowest sextile of educational attainment.

The strongest association is between the examination results and the social index, a rank correlation for the 107 individual LEAs of $0 \cdot 89$, social deprivation thus "explaining" four fifths of the variance in educational attainment. The mortality rates show similar if weaker trends, with correlations which range from 0.60 for infant mortality to 0.77 for male all cause mortality. All the rank correlations in the bottom row significantly differ from zero at the 0.0001 level.

Table 2 displays the characteristics of the LEA areas grouped into sextiles by their social index. The most affluent sextile of areas has the highest GCSE pass rate and the lowest rates on all five mortality measures. Examination pass rates tend to fall and mortality rates to rise from the most affluent to the most deprived sextile. For the individual areas the rank correlation of the social index is highest with male all cause mortality, lower with the other measures of adult mortality, and lowest with infant mortality. All the rank correlations in the bottom row significantly differ from zero at the 0.0001 level. In several cases the mortality rates in the most deprived sextile are lower than an incremental gradient would predict. An examination of the LEAs concerned shows that most of these are London boroughs.

The results of the regression analyses are presented in table 3 . The mortality rates which are presented are the means for the two extreme sextiles after adjustment for the designated variable (the corresponding unadjusted values appear in tables 1 and 2). For male and female all cause mortality, adjusting for social deprivation-affluence largely eliminates the association with education, while adjusting for education leaves the association with deprivation-affluence little changed. The opposite 
Table 3 Mortality indices by deprivation adjusted for GCSE pass rate, and by GCSE pass rate adjusted for deprivation

\begin{tabular}{|c|c|c|c|c|c|c|}
\hline \multirow[t]{2}{*}{ Mortality index } & \multicolumn{3}{|c|}{$\begin{array}{l}\text { Mortality by deprivation } \\
\text { adjusted for } G C S E^{*}\end{array}$} & \multicolumn{3}{|c|}{$\begin{array}{l}\text { Mortality by GCSE adjusted for } \\
\text { social deprivation* }\end{array}$} \\
\hline & $\begin{array}{l}\text { Most } \\
\text { deprived } \\
\text { sextile }\end{array}$ & $\begin{array}{l}\text { Most } \\
\text { affluent } \\
\text { sextile }\end{array}$ & $p$ (trend) & $\begin{array}{l}\text { Least } \\
\text { successful } \\
\text { sextile }\end{array}$ & $\begin{array}{l}\text { Most } \\
\text { successful } \\
\text { sextile }\end{array}$ & $p$ (trend) \\
\hline $\begin{array}{l}\text { Male all cause } \\
\text { Female all cause } \\
\text { Male CHD } \\
\text { Female CHD } \\
\text { Infant }\end{array}$ & $\begin{array}{c}11 \cdot 7 \\
7 \cdot 0 \\
1 \cdot 44 \\
0 \cdot 39 \\
7 \cdot 7\end{array}$ & $\begin{array}{l}9 \cdot 8 \\
6 \cdot 2 \\
1 \cdot 13 \\
0 \cdot 31 \\
7 \cdot 2\end{array}$ & $\begin{array}{l}0.0001 \\
0.005 \\
0.005 \\
0.09 \\
0.40\end{array}$ & $\begin{array}{l}10 \cdot 7 \\
6 \cdot 6 \\
1 \cdot 31 \\
0 \cdot 39 \\
7 \cdot 9\end{array}$ & $\begin{array}{l}9 \cdot 8 \\
6 \cdot 0 \\
1 \cdot 02 \\
0 \cdot 22 \\
6 \cdot 0\end{array}$ & $\begin{array}{l}0.03 \\
0.03 \\
0.006 \\
0.0001 \\
0.002\end{array}$ \\
\hline
\end{tabular}

* Fitted values from regression analysis.

$\mathrm{CHD}=$ coronary heart disease table to a pattern of individual level associations. ${ }^{15}$ Nevertheless, ecological relationships should be taken only as pointers to possible individual level relationships.

Since our measures of educational attainment and mortality refer to different generations, a simple individual level analogue of our ecological results is unlikely. Indeed, our education measure may be indexing a fundamentally ecological variable, ${ }^{16}$ namely the general cultural level of a community. This general cultural level could influence the educational attainment of the community's adolescents through normative expectations of its schools and the cultural resources of its parents. ${ }^{17}$ It could also influence the health, and hence the mortality, of the community's infants and adults through normative behaviour concerning infant care and adult cigarette smoking, diet, and physical exercise.

These results regarding the relative weight of the material and cultural dimensions of social class need to be investigated with individual level data, but on the basis of the present analyses we hypothesise that an area's educational level is a predictor of individual mortality.

We are grateful to Scott Montgomery of the Social Statistics Research Unit, City University; and to the Analytical Services Branch Department for Education, the Office of Population
Censuses and Surveys, and the Centre for Urban Policy Studies Censuses and Surveys, and the Centre for Urban Policy Studion
University of Manchester for information and assistance.

1 National Centre for Health Statistics. Health United States 1993. Hyattsville, MA: Public Health Service, 1994.

2 Guralnik JM, Land KC, Blazer D et al. Educational status and active life expectancy among older blacks and whites. $N$ Engl ₹ Med 1993;329:110-16.

3 Winkleby MA, Jatulis DE, Frank E, Fortmann SP. Socioeconomic status and health how education, income and occupation contribute to risk factors for cardiovascular occupation contribute to risk factors for cardicise. Am f Public Health 1992;82:816-20.
disease.

4 Mackenbach JP. Inequalities in health in The Netherlands according to age, gender, marital status, level of education, according to age, gender, marital status, level of education, degree of urbanis

5 Phillimore P, Beattie A. Health and inequality: the northern region 1981-1991. Newcastle: Department of Social Policy, University of Newcastle upon Tyne 1994

6 Braddon FEM, Wadsworth MEJ, Davies JMC, Cripps HA. Social and regional differences in food and alcohol consumption and their measurement in a national birth cohort. $\mathcal{f}$ Epidemiol Community Health 1988;42:341-9.

7 Kuh DJL, Cooper C. Physical activity at 36 years: patterns and childhood predictors in a longitudinal study. $\mathcal{F} E \mathrm{p}$ idemiol Community Health 1992;46:114-119.

$8 \mathrm{Kuh}$ DJL, Wadsworth MEJ. Physical health status at 36 years in a British national birth cohort. Soc Sci Med 1993; 37:905-16.

9 Power C, Manor O, Fox J. Health and class: The early years. London: Chapman Hall 1991.

10 Goldblatt $\mathrm{P}$ ed. Mortality and social organisation. LS series No6. London: HMSO 1990.

11 Department of the Environment. Index of local conditions. London: DoE 1994.

$12 S A S / S T A T$ guide for personal computers. Version 6 edition. Cary, NY: SAS institute.

13 Editorial. Measurement imprecision: ignore or investigate? Lancet 1992;339:587-8.

14 MacRae K. Socioeconomic deprivation and health and the ecological fallacy. $B M F$ 1994;309:1478-9.

15 Sloggett A, Joshi H. Higher mortality in deprived areas: community or personal disadvantage? BMF 1994;309: community

16 Schwartz $S$. The fallacy of the ecological fallacy: the potential misuse of a concept and the consequences. Am F Public Health 1994;84:819-24.

17 Halsey AH, Heath AF, Ridge JM. Origins and destinations: family, class and education in modern Britain. Oxford: Clarendon Press 1980. 